\title{
THE CHRISTOLOGY OF THE MARTYRDOM OF POLYCARP: MARTYRDOM AS BOTH IMITATION OF CHRIST AND ELECTION BY CHRIST
}

\author{
PAUl HARTOG" \\ Faith Baptist Theological Seminary
}

\begin{abstract}
The Martyrdom of Polycarp narrates a martyrdom 'according to the Gospel'. Numerous facets of the text echo the passion materials of the Gospels, and Polycarp is directly said to imitate Christ. Various scholars have discussed the imitatio Christi theme within the work. Such an approach focuses upon Christ as an exemplar of suffering to be imitated, through specific events of similar suffering. But the Christology of the Martyrdom of Polycarp is far richer than this focus alone. Jesus Christ is also the Son, Savior, eternal high priest, teacher, elector, king, and alternative kúpıoৎ to Caesar. As the sovereign kúpıs, he actively coordinates events and chooses martyrs from among his servants.
\end{abstract}

KEY WORDS: Polycarp, Christology, martyrdom, imitation, imitatio Christi, election

\section{Introduction}

Traditionally, when scholars have interpreted the Christological themes embedded within the Martyrdom of Polycarp (Mart. Pol.), they have emphasized Jesus Christ as a martyrological example to be imitated. This imitatio Christi or mimetic approach is commonly rooted in an understanding of the phrase 'a martyrdom according to the Gospel' (Mart. Pol. 1.1; 4.1; 19.1; 22.1). Many scholars have underscored that 'a martyrdom according to the Gospel' imitates Jesus' passion by repeating or recapitulating specific details. ${ }^{1}$

The Christology of Mart. Pol. was not discussed in A. R. Stark's The Christology in the Apostolic Fathers (1912). C. R. Moss's scholarly writings, which do discuss the Christology of Mart. Pol., emphasize the themes of imitatio Christi and alter Christus (2010a: 552-553; 2010b: 4-6; 2012: 63-64). Her work The Other Christs expertly dissects the notion of Christly imitation in Mart. Pol., examining the details and function of this mimesis (see Moss, 2010b: 3). One is also reminded of M. Franzmann's essay (2009) on imitatio Christi in Mart. Pol. But the Christology of the narrative is

* PAUl HARTOG (PhD 2000, Loyola University Chicago) is Professor of New Testament and Early Christian Studies at Faith Baptist Theological Seminary in Ankeny, Iowa, United States of America. Email: hartog.paul@gmail.com

1 See Lightfoot (1889: 365); Campenhausen (1964: 82-85); Guillaumin (1975); Saxer (1986: 27 33); Lieu (1996: 59-63); Camelot (1998: 200-201); and Wilhite (2014). 
fuller and richer than imitatio Christi alone. In this article, I wish to extend the study of the Christology found in Mart. Pol. as it now stands (including the colophons) beyond the theme of imitatio Christi. ${ }^{2}$

Some scholars have compiled lists of numerous, specific gospel parallels within Mart. Pol. ${ }^{3}$ Jesus predicted his execution (Mark 8:31; 9:31; 10:33-34), as did Polycarp (Mart. Pol. 5.2). Jesus entered into town on a donkey (Matthew 21:1-11), as did Polycarp (Mart. Pol. 8.1). Jesus waited to be betrayed (Luke 22:20-23, 39-54), as did Polycarp (Mart. Pol. 1.2). Jesus prayed with a few close companions (John 17:1-26), as did Polycarp (Mart. Pol. 5.1), and both prayed broadly for all believers. Jesus hosted a final meal (Matthew 26:17-29), as did Polycarp (Mart. Pol. 7.2). Jesus prayed again before his arrest (Matthew 26:36-46), as did Polycarp (Mart. Pol. 7.2-3). Jesus wished for God's will to be done (Mark 14:36), as did Polycarp (Mart. Pol. 7.1). Jesus heard a voice from heaven (John 12:27-28), as did Polycarp (Mart. Pol. 9.1). Jesus was betrayed by a close acquaintance at night (Matthew 26:47-49), as was Polycarp (Mart. Pol. 6.1-2). Jesus was pursued as if a criminal (Matthew 26:55; Mark 14:48; Luke 22:52), as was Polycarp (Mart. Pol. 7.1). Jesus neither turned himself in nor resisted arrest (Matthew 26:47-54), nor did Polycarp (Mart. Pol. 1.2; 7.2). Jesus was arrested outside the city proper (John 18:1), as was Polycarp (Mart. Pol. 5.1). Jesus interacted with a 'Herod' (Luke 23:6-12), as did Polycarp (Mart. Pol. 8.2-3). Jesus was questioned by a proconsul (John 18:2819:11), as was Polycarp (Mart. Pol. 9.2-11.2); and in both cases the Roman authority seemed reluctant to mete out execution and provided opportunity for dismissal. Jesus remained silent early in his trial (Matthew 26:63; Mark 14:61), as did Polycarp (Mart. Pol. 8.2). Jesus prayed at his place of execution (Matthew 27:46; Mark 15:34; Luke 23:34, 46), as did Polycarp (Mart. Pol. 14.1-15.1). Jesus was pierced (John 19:34), as was Polycarp (Mart. Pol. 16.1). Jewish leaders agitated opposition to both Jesus (John 19:12-16) and Polycarp (Mart. Pol. 12.2-13.1). Both traditions highlight Friday, the day of preparation (Luke 23:54; John 19:31; Mart. Pol. 7.1). And those who betrayed Polycarp received 'the punishment of Judas himself' (Mart. Pol. 6.2; see Lawson, 1961: 169).

\section{Imitatio Christi}

'In its basic meaning', explains Moss (2010b: 23), 'imitatio Christi refers to actions or words that imitate those of Christ... The idea can be expressed both linguistically using the mimesis word group and conceptually in passages that propose motivating admiration for the exemplum (Moss, 2010b: 7). On the colophons, see Hoover (2013).

3 For a similar parallel listing, see Hartog (2013: 205). For other listings, see Lightfoot (1889: 610-612); Müller (1908: 6-12); Barnard (1978: 226-228); Bastiaensen (1987: 601-605); Camelot (1998: 200-202); Hook and Reno (2000: 133-136); Dehandschutter (2007: 95). See also Dehandschutter (1979: 241-254).

PERICHORESIS $12.2(2014)$ 
mimicry of Jesus' behavior but do not explicitly use this terminology'. Martyrdom was 'the ultimate act of imitatio Christi' (York, 2011: 37). 'For a person to sacrifice his or her life for the faith is to practice the imitatio Christi in a special sense' (Loades, 1993: xv; cf. Castelli, 2004: 54). Such 'imitation', therefore, was a common theme of martyr literature (Pellegrino, 1958; Buschmann, 1998: 83-84; Hurtado, 2003: 619-625; Moss, 2010b: 46-48), and appears in the context of a call to 'endurance' in Pol. Phil. 8 (cf. Ign. Pol. 3; Ign. Smyrn. 4.2; Lawson, 1961: 163). Prior to Mart. Pol., Ignatius of Antioch expressed his desire to imitate the sufferings of Jesus (Ign. Rom. 6.3; cf. Tinsley, 1957; Swartley, 1973; McNamara, 1978; Kathanar, 1996; Moss, 2010b: 41-43; Petersen, 2013; Preiss, 1938; Reis, 2005).

In her impressive The Other Christs: Imitating Jesus in Ancient Christian Ideologies of Martyrdom, Moss (2010b: 46) explains: 'For ancient audiences of the acta, the observation that martyrs imitate Christ is obvious. The preponderance of allusions, quotations, and statements explicating martyrdom's value as an imitatio Christi render this statement banal; it is everywhere implied and frequently stated'. Imitation in a martyr text (a martyr act) 'means both the way that the genre of the martyr act-problematic as it is-imitates and interprets the gospel account, and also the way that the martyr is portrayed as or presumed to imitate Christ' (Moss, 2010b: 6). Martyrs could be construed as the ultimate disciples of Jesus, following him to the point of death, and therefore being worthy of imitation in their own right (Life of Anthony 89). As such, 'The presentation of the martyr as imitator of Christ was a delicate theological balancing act' (Moss, 2010b: 4). The theological implications could be viewed by some as 'inherently troubling' (Moss, 2010b: 22; cf. Griffin, 2013). Martyrs imitated Christ but they were not to replace him (cf. Mart. Pol. 17.2-3).

Moss adds that 'among scholars, the idea [imitatio Christi] is most closely associated with the Martyrdom of Polycarp, a text that has become a staple among students of early Christian martyrdom. Polycarp's imitatio is explicitly stated from the outset, where his conduct is compared to that of Jesus. Polycarp is part of a mimetic chain, one that connects the audience of the martyrdom to Christ himself' (Moss, 2010b: 46). Polycarp is 'the perfect imitator of Christ', and the 'allusions to the passion narrative reach an entirely new level' (Moss, 2010b: 56, 106). Moss (2010b: 57) reiterates, 'the author deftly but overtly weaves references to the Gospels throughout the account, beginning with an outright declaration of Polycarp's imitation and proceeds to mirror the passion narratives from the Garden of Gethsemane to the moment of death'. For Moss (2010a: 552-553, 557), these constructed parallels add to the dubious nature of the historicity of the account.

No doubt, a theme of imitatio Christi courses its way throughout Mart. Pol. (Moss, 2010b: 46-47). However, the use of exact Gospel literary texts is debated, with Holmes (2005: 417) finding no single, provable instance. Yet the notion of mimesis in the work is not merely theatrical imitation, so there may be a danger in trying to find as many exact parallels as possible (Waldner, 2004: 59). Some of the 
collected parallels seem rather weak or superficial (Dehandschutter, 2007: 96). ${ }^{4}$ Others seem awkward or even unduly forced (Hartog, 2013: 206). ${ }^{5}$ One also recognizes that Polycarp's execution diverged from Jesus' in various ways. As van Henten (1993: 715) notes, the parallels 'are never completely identical, so that the suitable distance between Polycarp and Jesus Christ is maintained' ${ }^{6}$ For example, while Jesus was nailed to the cross (as emphasized in Ign. Smyrn. 1.2; Acts of Carpus 37-41), Polycarp was tied to the cross instead, upon his insistence (Mart. Pol. 13.314.1). ${ }^{7}$ Moss (2010b: 58-59) argues that the Jesus-Polycarp parallelism does not exactly 'break down' at this 'crucial moment', but rather the Polycarpian narrative is influenced by the akedah of Isaac.

An intentional paralleling of Polycarp's passion with that of Jesus' (as reflected in multiple similarities throughout the narrative) seems absolutely undeniable. Otherwise, it remains 'difficult to explain why so many scholars have so regularly "found" them' (Hartog, 2013: 208). Moss (2013: 120) maintains that 'the parallels between the death of Jesus and the death of Polycarp are apparent to even the most cursory of readers'. And Wilhite (2014: 13) declares, 'the amount of material that parallels the Gospels is too extensive to attribute to coincidence or accidental mirroring' (cf. Moss, 2012: 63). As Jefford (2012: 97) concludes, 'From beginning to end, the bishop's arrest, trial, and execution are painted against the canvas of similar events in the life of Jesus of Nazareth as they are recorded in the New Testament Gospels'.

Nevertheless, the 'gospel parallels' do not exhaust the meaning of 'a martyrdom according to the gospel', as evidenced by the role of secondary imitation in Mart. Pol. (Hartog, 2010: 291). Polycarp was 'an eminent martyr whose martyrdom all desire to imitate because it transpired according to the Gospel of Christ' (Mart. Pol. 19.1). The author(s) desired that 'we also might become imitators of him' (1.2; cf. 18.3; 22.1), thus transforming Polycarp from an imitator of Jesus to a pattern to be imitated (Franzmann, 2009: 378). But if Polycarp's 'martyrdom according to the gospel' consisted primarily in exact details like riding into town on a donkey, being crucified on the 'day of preparation', etc., these events were beyond the recipients' control (and thus their ability to 'imitate' them). Therefore, the details of recapitulation cannot exhaust the meaning of 'a martyrdom accord-

4 For example, the paralleling of the statement of the author of Mart. Pol. and the centurion's statement at Jesus' cross in Luke 23:47 (see Wilhite, 2014: 19). I am grateful to S. Wilhite for allowing me access to his paper.

$5 \quad$ For example, the comparison of Polycarp's leg injury in disembarking from the carriage with the mistreatment of Jesus prior to his execution (see Wilhite, 2014: 18). The emphasis in Mart. Pol. 8.3 is how nobility just walks it off.

$6 \quad$ English translation from Buschmann (2010: 145).

7 See Dehandschutter (2007: 96) and Weinrich (1981: 178, n. 9). Cf., however, Moss (2010a: 555); Moss (2010b: 58-59); Moss (2013: 131-132). On Polycarp's martyrdom as a sacrifice, see (Moss, 2010b: 84). Moss (2010b: 58-59) describes Polycarp as trumping or excelling Christ in some facets. See also Moss (2013: 129, 133).

PERICHORESIS $12.2(2014)$ 
ing to the gospel' (Hartog, 2013: 208-209). Moreover, the Christology of Mart. Pol. is far richer than the mere recapitulation of details found in the Gospel passion narratives.

Moss (2010b: 4) states, 'In some narratives, such as the famous Martyrdom of Polycarp, the martyr is explicitly identified both as an imitator of Jesus and as a model for other Christians... At the same time, the author is keen to differentiate between Polycarp and Christ... To simply state that the martyrs imitate Christ does not exhaust what the imitation of Christ can tell us about either martyrdom or the history of ideas... By presenting martyrs as Christly imitators, the authors of the early martyrdom accounts provide scholars with a window into early Christian understandings of scripture, Christology, and soteriology'. The imitation theme does reflect Christology, as the martyrs are depicted as 'partners with Christ' (Mart. Pol. 6.2) who 'share in the cup of Christ' (14.2; cf. Johnson, 2013). ${ }^{8}$ But the Christology of Mart. Pol. also reflects a multi-faceted jewel rather than a focused prism alone.

\section{Christological Titles}

An examination of the fuller, richer Christology of Mart. Pol. could begin with an overview of the Christological titles found within the work. They include the following:

$7 x$ : The Lord [by itself] $(1.1 ; 1.2 ; 2.2 ; 2.3 ; 17.3 ; 18.3 ; 20.1)$

6x: Christ, your Christ, the Messiah [by itself] $(2.2 ; 6.2 ; 9.3 ; 14.2 ; 17.2 ; 19.1)$

5x: the Son, his Son, your beloved Son, your beloved and blessed Son [including instances of combination with other titles] $(14.1 ; 14.3$; 17.1; 20.2; Moscow Epilogue 3)

4x: Jesus Christ, the only begotten Jesus Christ (14.1; 14.3, 20.2; 21)

4x: Lord Jesus Christ, our Lord Jesus Christ (inscr.; 19.2; 22.3, Moscow Epilogue 3)

2x: King, my king $(9.3 ; 17.3)$

1x: High priest (14.3)

1x: The crucified one (17.2)

1x: Teacher (17.3)

1x: Savior (19.2)

1x: Helmsman (19.2)

1x: Shepherd (19.2)

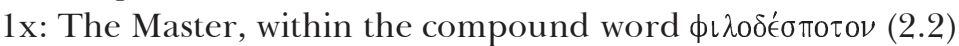

In the letter opening (and in 19.2), the Lord Jesus Christ is coupled with God the Father (cf. 22.3). The 'Lord' replaces 'God' in an allusion to 1 Corinthians 2:9 in 
Mart. Pol. 2.3 (see Hartog, 2015). This establishes the Lord as a revealing agent and parallels the use of 'Lord' in 2.2 (in a clearly Christological manner). The use of 'Christ' (Messiah) takes on a polemical tone in the context of Jewish opponents

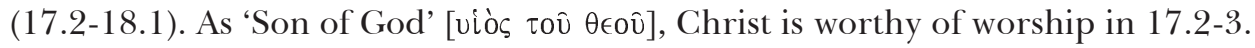

In Polycarp's prayer, Jesus Christ is not called the viò but the maí.. As I have argued elsewhere, the use of mais for the Son (or Servant) tends to be an early tradition that is overtaken by the use of viòs (Hartog, 2014: 41-44). The context in Mart. Pol. 14 emphasizes that 'knowledge' of the Father is received through the $\pi \alpha \hat{\imath} \varsigma$, Jesus Christ. This discussion of knowledge of the Father through the $\pi \alpha \hat{\imath} \varsigma$ is similar to Didache 9.2, which declares, 'We give you thanks, our Father, for the ho-

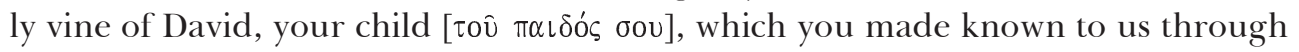

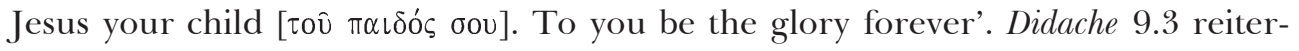
ates, 'We give you thanks, our Father, for the life and knowledge that you made

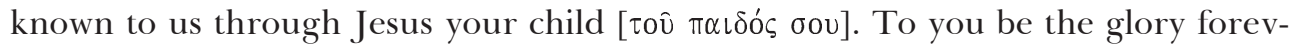
er'.

\section{Christ as King}

Perhaps the most fascinating facet of these Christological titles is the double use of 'King' (9.3 and 17.3). In 17.3, the title appears within a context of imitation: 'But we love the martyrs as disciples and imitators of the Lord, worthily because of their unsurpassed good will toward their own King and Teacher'. This text hints that Jesus is more than an example to be followed. He is also a king $\left[\beta \alpha \sigma L \lambda \lambda^{\prime}\llcorner\alpha]\right.$ to

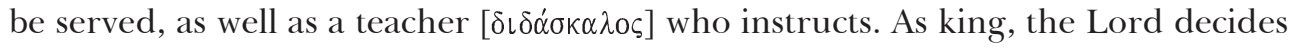
the future of his followers. The very next sentence adds a wish to become martyrological partners and fellow disciples (17.3): 'May we also become both [their] partners and fellow disciples!'

The title of 'king' is also found in the famous affirmation in 9.3: 'For eighty-six years I have been serving him, and he has done me no wrong. Indeed how can I blaspheme my king $\left[\beta \alpha \sigma L \lambda \lambda^{\prime} L \alpha\right]$ who saved me?' This text directly connects the king-

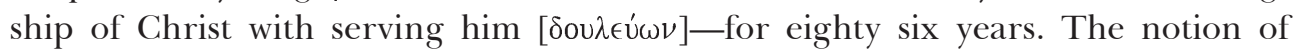
serving Jesus reappears in 20.1: 'Therefore, having learned these things, send the letter to the brothers further on in order that they too may glorify the Lord, who

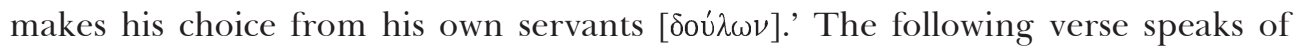

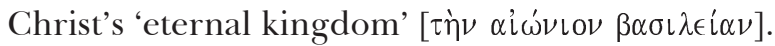

As one can see next, the following colophons speak of Jesus' reigning through-

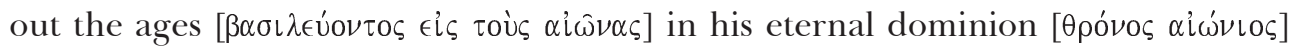

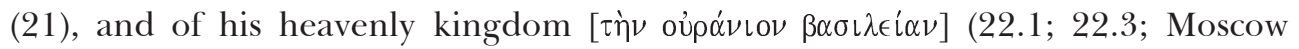
Epilogue 3). The text of 22.1 moves from the salvation of the elect ones to the personal desire to be found in the kingdom of Jesus Christ. The Lord's sovereignty is thus reflected in both election and kingdom entrance.

In an article recently appearing in Vigiliae Christianae, Hoover (2013: 15) comments upon the association in the colophons between the elect / chosen ones and the kingdom: 'Notice how both prayer and colophon are couched in a general 
context of association with the "chosen ones" / "martyrs" in the "heavenly kingdom" / "resurrection of eternal life", unlike the "glorification" theme that characterizes the Life [Vita Polycarpi]; furthermore, the prayer's double reference to the Son ("your beloved Son, through whom be glory to you, with him and the Holy Spirit”) retains close, if inexact, literary parallels with the Moscow colophon's doxology.'

\section{Christ as Savior and Priest}

Mart. Pol. 9.3 not only labels Christ as 'King', but also refers to his salvific work: 'my king who saved me [tòv $\sigma \omega ́ \sigma \alpha \nu \tau \dot{\alpha} \mu \epsilon]$ '. The work as a whole includes some other soteriological fascinations. Mart. Pol. 1.2 declares, 'For it is [characteristic] of true and firm love to desire not only oneself to be saved $[\sigma \omega \dot{\zeta} \zeta \sigma \theta \alpha \iota]$ but also all the brothers'. Mart. Pol. 17.2 refers to Christ 'who suffered for the salvation [ $\sigma \omega \tau \eta \rho i \alpha \varsigma]$ of the whole world of the saved [ $\tau \hat{\omega} \nu \sigma \omega \zeta o \mu \epsilon \nu \omega \nu$ ], the blameless on behalf of sinners'. This description refers to vicarious suffering, and the context in chapter 17 is anti-Jewish polemic. 'All this was done at the instigation and insistence of the Jews... They did not know that we will never be able either to abandon the Christ who suffered for the salvation of the whole world of those who are saved, the blameless on behalf of sinners, or to worship anyone else' (Holmes, 2007: 325). The Christ [Xpıøtós] could properly be translated as 'the Messiah' here. Within the context, the point seems to be that the Messiah did not die for Jews alone, but for the salvation of the whole world of the saved.

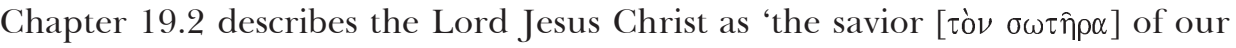
souls and pilot of our bodies and shepherd of the universal church throughout

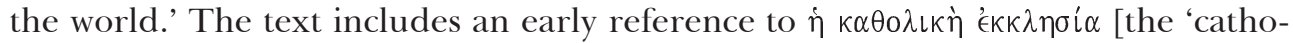
lic church' or 'universal church']; and it emphasizes a future for both soul and body. One is reminded of the portrayal of Polycarp's prayer from the stake in 14.2: 'I bless you because you have considered me worthy of this day and hour, to receive a portion in [the] number of the martyrs in the cup of your Christ, unto [the] resurrection of eternal life-both of soul and of body-in the immortality of the Holy Spirit' (Hartog, 2014).

In this context, one could also speak of the priestly work of Christ in 14.3: 'For this reason, and for all things, I praise you, I bless you, I glorify you through the

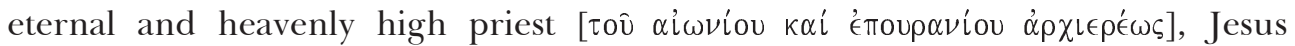
Christ, your beloved Son ...' The theology of Jesus as 'the eternal high priest' and 'Son of God' parallels the Christology of the books of Hebrews $(4.14 ; 6.20 ; 7.3$; 10:29) and 1 Clement $\left(36.1 ; 61.3 ; 64\right.$; cf. Ign. Phld. 9.1). ${ }^{9}$ Interestingly, 'the eternal high priest' is also found in Pol. Phil. 12.2, in the extant Latin (sempiternus pontifex). Thus the Messianic offices of king and priest are both associated with Jesus in 
Mart. Pol., while the office of prophet is never thus attached. Polycarp, on the other hand is said to speak prophetically $(5.2 ; 12.3)$ and to be an 'apostolic and pro-

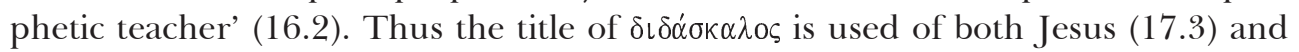
Polycarp (16.2).

\section{Christ as Sovereign Elector}

In the Mart. Pol., Jesus Christ chooses his servants and brings them into his kingdom (20.1-20.2): 'Therefore, having learned these things, send the letter to the brothers further on in order that they too may glorify the Lord, who makes his

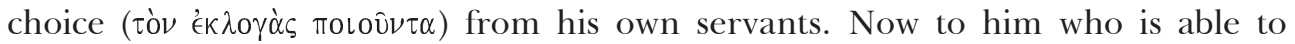
bring us all through his grace and bounty into his eternal kingdom through his Son, the only begotten Jesus Christ...' Divine choice is assumed in the references to 'the elect' in 16.1, 'his elect' (22.3; Moscow Epilogue 3), and 'the holy elect' (22.1). While 'the elect' in the colophons could be taken in a soteriological manner, as in the distinction between 'the unbelievers and the elect' in 16.1, the sense is narrower in 20.1: the Lord chooses from among his own those special servants who are to be martyrs. This martyrological sense of election lies behind the language of Polycarp 'fulfilling his own lot' (6.2) and being counted worthy of the day and hour, 'to receive a portion in [the] number of the martyrs' (14.2). The concept of being chosen to suffering was not uncommon in early Christian martyr texts (Brown, 1981: 72; cf. Philippians 1:29), as faithful victims were 'part of an elect family of martyrs' (Moss, 2010b: 163). It is important to stress the Christological source of election in Mart. Pol., as Jesus Christ the Lord chooses martyrs from among his own servants (20.1; cf. Moscow Epilogue 3).

Of course, election is affiliated with God's will, an important facet in Mart. Pol. Paralleling Jesus' Gethsemenaean prayer, Polycarp declares, 'The will of God be done' (7.1). In the context of chapter 7, Polycarp could have escaped to another farm, 'but he did not wish [to], saying, "The will of God be done".' This verse echoes chapter 2.1: 'Blessed and noble, therefore, [are] all the martyrdoms that have happened according to the will of God. For it is necessary for us, being very devout, to ascribe to God the authority over all things.'

\section{Christology and 'According to the Gospel'}

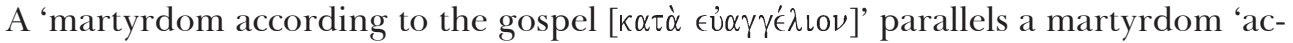
cording to the will of God' in 2.1. (cf. 19.1-20.2; Dehandschutter, 2007: 98). Holmes (2005: 420-421; 2007: 300), following Weinrich (1981: 167-168) and Buschmann (1998: 83), has argued that chapter two serves as a three-fold thematic focusing of the Mart. Pol. Such a martyrdom is one that '(a) is a matter of divine calling rather than human accomplishment or initiative', '(b) demonstrates a concern for the salvation or well-being of others' (1.2), and '(c) displays endurance in the midst of suffering' (2.1-2.2; 19.1-19.2). The main theme of Mart. Pol. (a 'martyrdom according to the gospel') thus stands as 'the fruit of an act of interpretation' (Holmes, 2005: 421-422). All three of these traits can be viewed through a 
Christological prism. Jesus Christ sovereignly chooses his martyrs, Jesus Christ also was concerned with the salvation of others, and Jesus Christ also displayed endurance in suffering.

All of these same themes appear in Paul's Philippians 1:20-2:17 (Hartog, 2010; cf. McClain, 2014: 341-342). ${ }^{10}$ If this is the case, Mart. Pol. may not only be constructing a 'martyrdom according to the Gospel' with Jesus' passion narratives in mind, it may also have 'conduct worthy of the Gospel' (Philippians 1:27) in mind. Such 'conduct worthy of the Gospel' is associated with the desire for Christ to be exalted in one's body 'whether by life or by death' (Philippians 1:20; cf. Fowl, 2011), and it entails the command to 'look out not only for personal interests, but also for the interests of others' (Philippians 2:4). This latter verse from Paul's Philippians is echoed in Mart. Pol. 1.2: 'not only looking out for that which concerns ourselves but also that which concerns our neighbors' (see Hartog, 2010: 393). Such a reception places a new interpretive grid upon Mart. Pol. 4: 'Therefore, on account of this, brothers, we do not praise those who hand themselves over, because the gospel does not so teach.' Thus a 'martyrdom according to the Gospel', and by extension a martyrdom according to God's will, is contrasted with the problematic actions of Quintus in Mart. Pol. 4 (Hartog, 2013: 275).

One might add a fourth trait of a 'martyrdom according to the gospel': it is characterized by 'nobility' (Hartog, 2010: 392; Hartog, 2013: 207-208). ${ }^{11}$ Like the other three traits described above, this characteristic appears in the thematic passage of Mart. Pol. 1-2 [where the $\gamma \in \nu \nu \alpha$ ios word group appears four times]. ${ }^{12}$ The $\gamma \in \nu \nu \alpha$ io $\_$word group re-appears twice more in chapter 3, with references to 'noble' Germanicus and 'the whole crowd' marveling at the 'nobility of the God-loving and God-fearing race of the Christians'. Of course, as Droge and Tabor (1992) as well as van Henten and Avemarie (2002) and others have demonstrated, this characteristic of nobility is commonly found among the Jewish, pagan, and early Christian martyr texts of the broader era. And the portrayal of Polycarp within Mart. Pol. manifests some affinities with the image of Socrates (Geffcken, 1910: 500-501; Benz, 1950-1951; Butterweck, 1995: 8-22; York, 2011: 34-39; Moss, 2013: 134; Cobb, 2014). ${ }^{13}$ Nevertheless, the thrust of Mart. Pol. 1-2 is Christologi11.1 .

11 Wilhite (2014: 12) accepts and adapts this fourth characteristic. Of course, many martyr texts stressed the 'nobility' (or courage) of the victim, so the trait is not at all unique to Mart. Pol. (cf. Mart. Lyons 1.17-19). Buschmann (1995: 112-115, 127) emphasizes the 'calm patience', 'calm serenity', and 'quiet serenity' of Polycarp in contrast to his 'enthusiastic' opponents. Buschmann (1994: 64) further contrasts the restlessness of Ignatius with the serenity of Polycarp. See also McCready (2005: 148, 150).

12 That is, four times in Dehandschutter's critical edition (2007), which supports one instance ( $\gamma \in \nu \nu \alpha \iota$ ó $\alpha \tau \sigma \iota)$ not found in the editions of Ehrman (2003) and Holmes (2007).

13 Because of the timing of publication overlaps, I was unable to interact directly with the full article of Cobb (2014) [only an abstract]. For a wider context of the Socratic tradition, see 
cal in focus. The martyrs were noble because 'the Lord was beside them, conversing with them' (2.2), and 'they despised the earthly torments' because they gave attention to 'the grace of Christ' (2.3).

The joint concept of 'a martyrdom according to the Gospel' and a martyrdom 'according to God's will' is thus embedded within a wider framework of divine sovereignty that weaves its way throughout the Mart. Pol. In a sense, God is the stage director of the drama, divinely superintending all events. This divine sovereignty leads to a sense of necessity within the narrative. It was 'impossible' for Polycarp to remain hidden, because he had to 'fulfil his own lot, becoming a partner of Christ' (6.2). It was 'necessary' that Polycarp's vision of the burning pillow be fulfilled in his own burning at the stake (12.3; cf. Kozlowski, 2009). He resolutely declared, 'It is necessary for me to be burned alive' (12.3). The Christian witnesses were 'preserved in order to announce to the rest the things that happened' (15.1). Mart. Pol. 2:1 summarizes this mindset: 'For it is necessary for us, being very devout, to ascribe to God the authority over all things'.

Interestingly, in light of our Christological interest, this divine sovereignty is focused upon the 'Lord' (кúpıos) in chapter 1. 'For nearly all the preceding things happened in order that the Lord might show to us again the martyrdom in accordance with the gospel' (1.1). While kúp ıoৎ could be a term for God in a general manner, the context narrows the meaning in a Christological fashion. The preceding verse refers to 'God the Father and our Lord Jesus Christ' (inscription). And the following verse states that Polycarp waited to be betrayed 'as also the Lord did, in order that we also might become imitators of him, not only looking out for that which concerns ourselves but also that which concerns our neighbors' (1.2). Only the Son was betrayed, and the allusion to Philippians 2.4 heightens the Christological focus of kúpıos.

In fact, apart from the prayerful ascription in Mart. Pol. 14.1, kúp los can be interpreted consistently as a Christological title throughout the work (similar to the general usage within the Pauline literature). With the final occurrence found in chapter 18, in the context of the internment of Polycarp's remains, the narrator declares, 'Gathering there together with gladness and joy, so far as possible, the Lord will permit to celebrate the birthday of [Polycarp's] martyrdom, both for the commemoration of those previous contestants and for the training and preparation of ones to come'. From beginning to end, the Lord is sovereign in the affairs of the chosen martyrs and their fellow disciples.

Garrison, Mejer, and Döring (1978). The portrayal of Polycarp also resembles that of Stephen in Acts 6:15 (Mart. Pol. 12). Like Stephen, Polycarp stoked the reactive anger of his opponents, was strengthened directly by Christ, and had a wondrous countenance in facing death (Franzmann, 2009: 371). According to Franzmann (2009: 374), 'Polycarp imitates even more strongly the death of Stephen than the death of Jesus'. The preponderance of parallels, however, fit Christ more than Stephen. See also Buschmann (1994: 237-239). For a comparison between Polycarp and Indian gymnosophists, see Kozlowski (2011).

PERICHORESIS $12.2(2014)$ 


\section{Conclusion}

With this final text, we have come full circle. Yes, there is a definite theme of imitatio Christi within Mart. Pol. Polycarp imitated his Lord, and the others in turn were to imitate Polycarp. There indeed would be 'the training and preparation' of future martyrs (18.3). But Jesus Christ is not merely the object whom the believer intentionally follows, but also the subject who directs all human affairs (18.3), including martyrdom (14.2). 'Consequently, the transformation that changes both Polycarp and his witness is also a transformation wrought by Christ in which the whole church participates and is changed' (McClain, 2014: 345). In this Christological paradigm, Jesus Christ the Lord does not play merely a passive role of historical exemplar, but he plays an active and contemporary role, choosing elect martyrs from among his servants (20.1), enabling Polycarp to endure (13.3), standing by the martyrs and speaking to them (2.2), and directing all human affairs as the King.

Within the context of Mart. Pol., Christological kingship plays a political, antiimperial role. Herod the irenarch and his father Nicetes insisted, 'For what harm is it to say "Caesar is Lord" and to offer incense?' (8.2). The proconsul persisted, 'Swear, and I will release you. Revile Christ!' (9.3). It is interesting that Polycarp responds, 'For eighty-six years I have been serving him, and he has done me no wrong. Indeed how can I blaspheme my king who saved me?' Polycarp cannot serve Caesar in the way requested, because he serves another king. The alternative politic becomes explicit in chapter 21: '[Polycarp] was arrested by Herod in [the] high priesthood of Philip [the] Trallian, Statius Quadratus being proconsul, but while Jesus Christ reigns throughout the ages...' Jesus Christ is depicted both as an alternative high priest to Philip the Trallian and as an alternative King to the Roman rulers.

Jesus is certainly an example of suffering to be imitated in Mart. Pol. But the Christology of Mart. Pol. is far richer than an imitatio Christi focus alone, whether the general imitation of Christ as a model figure or the recapitulation of specific details from his passion narratives. As the sovereign king, Jesus Christ is more than a model object for imitation. He is an active agent in the unfolding narrative itself, directing the drama even as he wills and chooses. Within Mart. Pol., Jesus Christ is more than a historical exemplar to be followed in suffering, but a living and active priest, shepherd, and king. Mart. Pol. reflects a fuller and richer Christology than imitatio Christi or alter Christus alone. Jesus Christ is the Son, Savior, eternal high priest, teacher, elector, king, and alternative kúp ıos to Caesar. ${ }^{14}$

14 I wish to thank those who shared helpful insights after the presentation of these materials at the Patristic, Medieval, and Renaissance Conference held at Villanova University, 24-26 October 2013; and at the International Society of Biblical Literature conference held at the University of Vienna, 6-10 July 2014.

PERICHORESIS 12.2 (2014) 


\section{Bibliography}

Barnard, LW (1978) In Defence of Pseudo-Pionius' Account of Polycarp's Martyrdom. In Studies in Church History and Patristics. Thessaloniki: Patriarchikon Hidryma Paterikon Meleton.

Bastiaensen, AAR, et al. (1987) Atti e passion dei martiri. Milano: Lorenzo Valla.

Bauer, JB (1995) Die Polykarpbriefe (Kommentar zu den Apostolischen Vätern 5). Göttingen: Vandenhoeck \& Ruprecht.

Benz, E (1950-1951) Christus und Socrates in der alten Kirche. Zeitschrift für die neutestamentliche Wissenschaft und die Kunde der älteren Kirche 43(1): 195-224.

Brown, P (1981) The Cult of the Saints: Its Rise and Function in Latin Christianity. Chicago, IL: University of Chicago Press.

Buschmann, G (1994) Martyrium Polycarpi: Eine formkritische Studie. Ein Beitrag zur Frage nach der Entstehung der Gattung Märtyrerakte (Beihefte zur Zeitschrift für die neutestamentliche Wissenschaft und die Kunde der älteren Kirche 70). Berlin: Walter de Gruyter.

Buschmann, G (1995) Martyrium Polycarpi 4 und der Montanismus. Vigiliae Christianae 49(2): 105-145.

Buschmann, G (1998) Das Martyrium des Polykarp (Kommentar zu den Apostolischen Vätern 6). Göttingen: Vandenhoeck \& Ruprecht.

Buschmann, G (2010) The Martyrdom of Polycarp. In Pratscher, W (ed) The Apostolic Fathers: An Introduction. Waco, TX: Baylor University Press.

Butterweck, C (1995) 'Martyriumssucht' in der alten Kirche? Studien zur Darstellung und Deutung frühchristlicher Martyrien (Beiträge zur historischen Theologie 87). Tübingen: Mohr Siebeck.

Camelot, PT (1998) Ignace d'Antioche, Polycarpe de Smyrne: Lettres, Martyre de Polycarpe, fourth edition revised and corrected. Sources chrétiennes, volume 10. Paris: Cerf.

von Campenhausen, HF (1964) Die Idee des Martyriums in der alten Kirche, second edition. Göttingen: Vandenhoeck \& Ruprecht.

Castelli, EA (2004) Martyrdom and Memory: Early Christian Culture Making. New York, NY: Columbia University Press.

Cobb, LS (2014) Polycarp's Cup: Imitatio in the Martyrdom of Polycarp. Journal of Religious History 38(2): 224-240.

Dehandschutter, B (1979) Martyrium Polycarpi: Een literair-kritische studie (BETL 52). Leuven: Leuven University Press.

Dehandschutter, B (2007) Polycarpiana: Studies on Martyrdom and Persecution in Early Christianity, Leemans, J (ed) Bibliotheca Ephemeridum Theologicarum Lovaniensium 205. Leuven: Leuven University Press.

Droge, AJ and Tabor, JD (1992) Noble Death: Suicide and Martyrdom among Christians and Jews in Antiquity. San Francisco, CA: Collins. 
Ehrman, B (2003) Apostolic Fathers, volume 1: 1 Clement, 2 Clement, Ignatius, Polycarp, Didache (Loeb Classical Library). Cambridge, MA: Harvard University Press.

Fowl, S (2011) The Primacy of the Witness of the Body to Martyrdom in Paul. In Budde, ML and Scott, K (eds) Witness of the Body: The Past, Present, and Future of Christian Martyrdom. Grand Rapids, MI: Eerdmans.

Franzmann, M (2009) Imitatio Christi: Copying the Death of the Founder and Gaining Paradise. In Rodgers, Z; Daly-Denton, M and Fitzpatrick-McKinley, A (eds) A Wandering Galilean: Essays in Honour of Seán Freyne (Supplements to the Journal of the Study of Judaism 132). Leiden: Brill.

Garrison, DH; Mejer, J and Döring, K (1979) Exemplum Socratis. Studien zur Sokratesnachwirkung in der kynisch-stoischen Popularphilosophie der frühen Kaiserzeit und im frühen Christentum (Hermes Einzelschriften 42). Wiesbaden: Franz Steiner.

Geffcken, J (1910) Die christlichen Martyrien. Hermes 45: 481-505.

Griffin, D (2013) Imitatio Christi: On Easing Some Concerns. Lutheran Theological Journal 47(1): 22-30.

Guillaumin, ML (1975) En marge du 'Martyre de Polycarpe': Le discernement des allusions scripturaires. In Bellis, M (ed), Forma futuri. Torino: Bottega d'Erasmo.

Hartog, P (2010) Polycarp's Martyrdom 'According to the Gospel' and Paul's Philippians. Studia Patristica 45.

Hartog, P (2013) Polycarp's Epistle to the Philippians and the Martyrdom of Polycarp (Oxford Apostolic Fathers). Oxford: Oxford University Press.

Hartog, P (2014) The Nascent 'Trinitarian' Worship of Martyrdom of Polycarp 14 and Ephesians 1. In Anatolios, K (ed) The Holy Trinity in the Life of the Church (Holy Cross Studies in Patristic Theology and History). Grand Rapids, MI: Baker.

Hartog, P (2015) 1 Corinthians 2:9 in the Apostolic Fathers. In Bingham, J and Jefford, CN (eds) Intertextuality in the Second Century (Bible in Ancient Christianity). Leiden: Brill, forthcoming.

Hernando, JD (1990) Irenaeus and the Apostolic Fathers: An Inquiry into the Development of the New Testament Canon, PhD dissertation. Madison, NJ: Drew University.

Holmes, MW (2005) The Martyrdom of Polycarp and the New Testament Passion Narratives. In Gregory, A and Tuckett, C (eds) Trajectories through the New Testament and the Apostolic Fathers. Oxford: Oxford University Press.

Holmes, MW (2007) The Apostolic Fathers: Greek Texts and English Translations, third edition. Grand Rapids, MI: Baker.

Hook, BS and Reno, RR (2000) Heroism and the Christian Life: Reclaiming Excellence. Louisville, KY: Westminster John Knox. 
Hoover, J (2013) False Lives, False Martyrs: 'Pseudo-Pionius' and the Redating of the Martyrdom of Polycarp. Vigiliae Christianae 67(5): 1-28.

Hurtado, LW (2003) Lord Jesus Christ: Devotion to Jesus in Earliest Christianity. Grand Rapids, IL: Eerdmans.

Jefford, CN (2012) Reading the Apostolic Fathers: An Introduction, second edition. Peabody, MA: Hendrickson.

Johnson, ME (2013) Sharing 'the Cup of Christ': The Cessation of Martyrdom and Anaphoral Development. In Hawkes-Teeples, S; Groen, B and Alexopoulos, S (eds) Studies on the Liturgies of the Christian East (Early Christian Studies 18). Leuven: Peeters.

Kathanar, KT (1996) Ignatian Vision of Christian Life as Imitation of Christ. Christian Orient 17(3): 199-127.

Kozlowski, JM (2009) 'And He Saw His Pillow Being Consumed by Fire' (Martyrium Polycarpi 5.2): A Proposal of Interpretation. Ephemerides Theologicae Lovanienses 85(1): 147-158.

Kozlowski, JM (2011) Polycarp as a Christian Gymnosophist. Studia Patristica 51: $15-22$.

Lawson, J (1961) A Theological and Historical Introduction to the Apostolic Fathers. New York, NY: Macmillan.

Lieu, JM (1996) Image and Reality: The Jews in the World of the Christians in the Second Century. Edinburgh: T\&T Clark.

Lightfoot, JB (1889) The Apostolic Fathers: Clement, Ignatius, and Polycarp, volume. 2.3, second edition. London: Macmillan.

Loades, D (1993) Introduction. In Wood, D (ed) Martyrs and Martyrologies. Oxford: Blackwell.

McClain, DW (2014) Repurposing the Body: Sacramentality and the Poetics of Discipleship. Anglican Theological Review 96(2): 339-356.

McCready, WO (2005) Martyrdom: In Accordance with the Gospel. In Ascough, RS (ed) Religious Rivalries and the Struggle for Success in Sardis and Smyrna (ESCJ 14). Waterloo: Wilfrid Laurier University Press.

McNamara, DM (1975) Ignatius of Antioch on his Death: Discipleship, Sacrifice, Imitation, $\mathrm{PhD}$ dissertation. Hamilton, ON: McMaster University.

Moss, CR (2010a) On the Dating of Polycarp: Rethinking the Place of the Martyrdom of Polycarp in the History of Christianity. Early Christianity 1: 539-574.

Moss, CR (2010b) The Other Christs: Imitating Jesus in Ancient Christian Ideologies of Martyrdom. New York, NY: Oxford University Press.

Moss, CR (2012) Ancient Christian Martyrdom. New Haven, CT: Yale University Press.

Moss, CR (2013) Nailing Down and Tying Up: Lessons in Intertextual Impossibility from the Martyrdom of Polycarp. Vigiliae Christianae 67(2): 117-136.

Müller, H (1908) Das Martyrium Polycarpi: Ein Beitrag zur altchristlichen Heiligengeschichte. Römische Quartalschrift 22: 1-16.

PERICHORESIS $12.2(2014)$ 
Oxford Society of Historical Theology (1905) The New Testament in the Apostolic Fathers. Oxford: Clarendon.

Pellegrino, M (1958) L'imitation du Christ dans les Actes des Martyrs. La vie spirituelle 98: 38-54.

Petersen, AK (2013) Attaining Divine Perfection through Different Forms of Imitation. Numen 60(1): 7-38.

Preiss, T (1938) La mystique de l'imitation du Christ et de l'unité chez Ignace d'Antioch. Revue d'histoire et de philosophie religieuses 18: 197-241.

Reis, DM (2005) Following in Paul's Footsteps: Mimésis and Power in Ignatius of Antioch. In Gregory, A and Tuckett, C (eds) Trajectories through the New Testament and the Apostolic Fathers. Oxford: Oxford University Press.

Saxer, V (1986) Bible et Hagiographie: Textes et thèmes bibliques dans les Actes des martyrs authentiques des premiers siècles. Bern: Peter Lang.

Stark, AR (1912) The Christology in the Apostolic Fathers. Chicago, IL: University of Chicago Press, 1912.

Swartley, WM (1973) Imitatio Christi in the Ignatian Letters. Vigiliae Christianae 27(2): 81-103.

Tinsley, EJ (1957) The imitatio Christi in the Mysticism of St. Ignatius of Antioch. Studia Patristica 2: 553-560.

van Henten, JW (1993) Zum Einflu $\beta$ jüdischer Martyrien auf die Literatur des frühen Christentums. II: Die Apostolischen Väter. In Temporini, H and Haase, W (eds) Aufstieg und Niedergang der Römischen Welt II.27.1. Berlin: Walter de Gruyter.

van Henten, JW and Avemarie, F (2002) Martyrdom and Noble Death: Selected Texts from Graeco-Roman, Jewish and Christian Antiquity (Context of Early Christianity). London: Routledge.

Waldner, K (2004) 'Was wir also gehört und berührt haben, verkünden wir auch euch...' Zur narrativen Technik der Körperdarstellung im Martyrium Polycarpi und der Passio Sanctarum Perpetuae et Felicitatis. In Feichtinger, B and Seng, H (eds) Die Christen und die Körper: Aspekte der Körperlichkeit in der christlichen Literatur der Spätantike. München: Saur.

Weinrich, WC (1981) Spirit and Martyrdom: A Study of the Work of the Holy Spirit in Contexts of Persecution and Martyrdom in the New Testament and Early Christian Literature. Washington, DC: University Press of America.

Wilhite, S (2014) 'The Martyrdom of Polycarp as Imitatio Christi: A Pedagogical Reshaping of Polycarp's Passion for Ethical Imitation.' Paper presented at Greek Reading Group, Southern Baptist Theological Seminary, Louisville, KY, 17 June 2014.

Williams, HHD (2013) 'Imitate Me': Interpreting Imitation in 1 Corinthians in Relation to Ignatius of Antioch. Perichoresis 11(1): 75-94. 
York, T (2011) Early Church Martyrdom: Witnessing For or Against the Empire? In Budde, ML and Scott, K (eds) Witness of the Body: The Past, Present, and Future of Christian Martyrdom. Grand Rapids, MI: Eerdmans. 